\title{
A new species of Neopaulinella (Brachiopoda, Terebratulida) from the Eastern Iberian Chains, Spain (Lower Devonian)
}

\author{
MENA SCHEMM-GREGORY
}

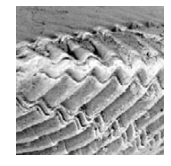

\begin{abstract}
A new terebratulid brachiopod species, Neopaulinella noguerasensis, has been identified from the Nogueras Formation of the Eastern Iberian Chains (Spain). It is compared with the other known species of Neopaulinella from France and Spain, $N$. guerangeri and $N$. gaudryi, from which it differs in size of costae, dental plates, and dorsal adductor field including the dorsal median septum. Digitized three-dimensional reconstructions of the internal shell and the loop of the new species are presented. The life habit of $N$. noguerasensis is briefly discussed regarding its palaeoecological environment. The cladistical analysis show an equal relationship to the other species of Neopaulinella. The phylogeny of the genus and migration paths of its species are demonstrated. The palaeobiogeographical distribution of Neopaulinella reflects the Early Devonian provincialism and suggests a migration path between Western and Central Europe during Siegenian time. - Keywords: Paulinella, Terebratulida, Brachiopoda, 3D reconstruction, palaeobiogeography, Lower Devonian, Spain.
\end{abstract}

SCHEMM-GREGORY, M. 2011. A new species of Neopaulinella (Brachiopoda, Terebratulida) from the Eastern Iberian Chains, Spain (Lower Devonian). Bulletin of Geosciences 86(2), 227-240 (10 figures, 4 tables). Czech Geological Survey, Prague. ISSN 1214-1119. Manuscript received November 10, 2010; accepted in revised form January 14, 2011; published online February 24, 2011; issued June 20, 2011.

Mena Schemm-Gregory, Centro de Geociências da Universidade de Coimbra, Largo Marquês de Pombal, P-3000-272 Coimbra, Portugal; Mena.Schemm-Gregory@dct.uc.pt

The Eastern Iberian Chains (Spain) belong to the northern Gondwanan regions within the Rhenohercynian and are characterized by Lower Devonian strata similar to successions in the Dra Valley (Morocco) represented by rhythmic sequences of limestone, sandstone, and clay (Jansen et al. 2007). In contrast to the strata in Morocco, strata of the Eastern Iberian Chains have undergone a complicate tectonic deformation. The intercalation of strata representing the hercynian (pelagic) facies and the rhenish (neritic) facies in the Eastern Iberian Chains allows correlation of Lower Devonian rocks between North Africa, Central and Western Europe, and Bohemia (e.g., Jansen 2001, Jansen et al. 2007, Schemm-Gregory 2008a). Subsequently, the Subcommission on Devonian Stratigraphy (SDS) is paying special attention to their research. Although the Eastern Iberian Chains are important for correlation between today's North Africa, Central and Western Europe, the first studies of this mountain range began only 50 years ago. Since this time intensive geological and palaeontological research has been carried out. Detailed lithological and biostratigraphical divisions are published by Carls (1969, 1971, 1975, 1977, 1987, 1988, 1996a, b, 1999), Carls et al. (1972, 1982, 1993), Carls \& Gandl (1967, 1969), and
Gandl (1972); special attention has been paid to the brachiopods by Carls (1974, 1985, 1986) and Carls et al. (1993), however, these studies focus mainly on spiriferids due to their biostratigraphic value.

The material used in this study has been collected within the frame of geological/palaeontological field trips by German and Spanish members of the SDS. The study area is situated in the Eastern Iberian Chains in the northwestern part of the topographical mapsheet 466 (Moyuelo, ex Blesa) (Fig. 1). A detailed description of the collection locality is given in Carls (1987). The specimens studied occur in the d2c-beta bed of the Nogueras Formation which represents a time interval from the Late Gedinnian to the Early Siegenian (early to middle Early Devonian). It follows the Luesma Formation and is overlain by the Santa Cruz Formation (Fig. 2). The d2c-beta bed represents the uppermost part of the Formation of Early Siegenian age.

Most of the type regions of neritic Lower Devonian strata of Europe are in the Rheinisches Schiefergebirge (= Rhenish Slate Mountains) (Germany), or in the Ardennes (Belgium, France), however, these regions are characterized by the absence of fully marine biofacies from 


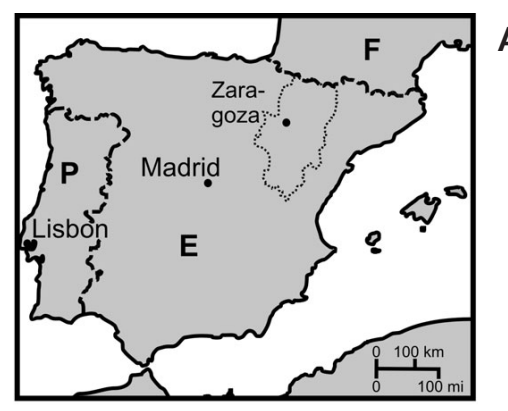

A
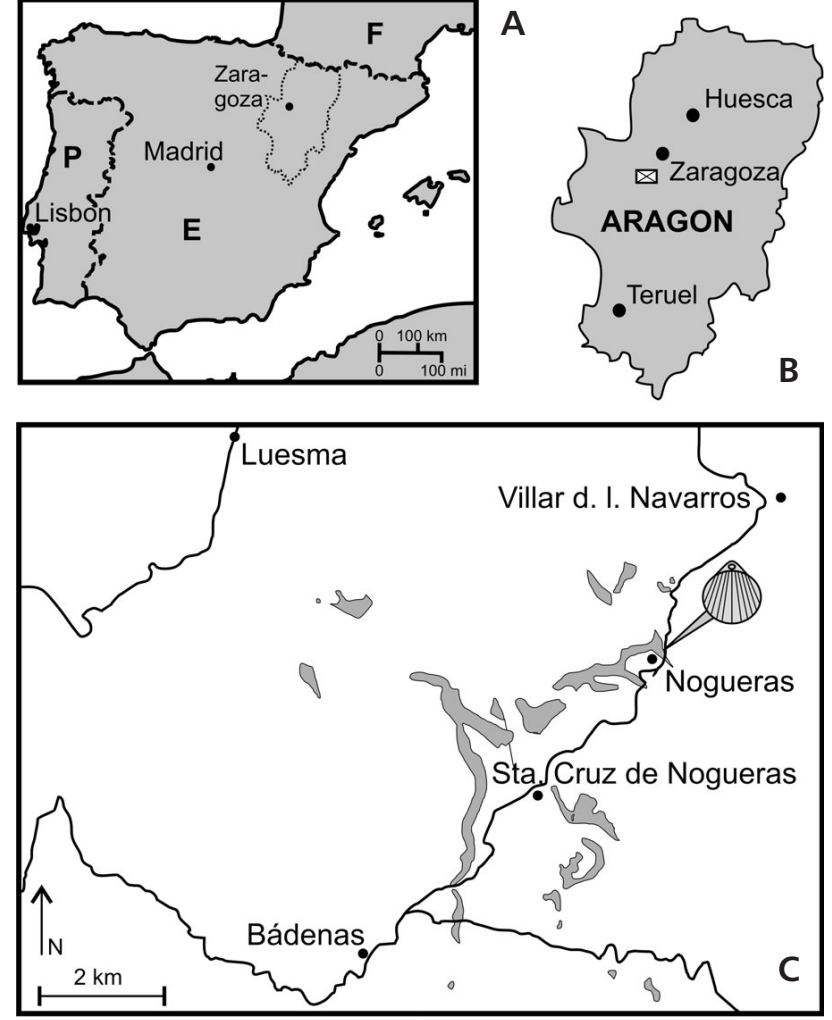

Figure 1. Topographical map of the Iberian Peninsula (A), the Province of Aragon (B), and the study area (C). Black lines represent streets. Outcrops of the Nogueras Formation highlighted in grey. Collecting locality indicated by the brachiopod symbol. Modified after Carls (1987); $\mathrm{E}=$ Spain, $\mathrm{F}=$ France, $\mathrm{P}=$ Portugal.

Late Gedinnian through most of Early Siegenian time. The last marine fauna before this gap is found on the dumontianus shelf in the Taunus Hills (Germany) and the Ardennes and describes a late Pridolian transgression (Carls 1987, Schemm-Gregory \& Jansen 2009). The following transgression does not start before Middle Siegenian time. To study the stratigraphy and correlation of this time interval, special attention is paid to the Armorican Massif (France), the Cantabrian Mountains and Eastern Iberian Chains (both Spain) which contain extensive invertebrate faunas of this particular time interval. Several horizons with characteristic index fossils can be correlated within and also between these three regions. Especially the Eastern Iberian Chains show several faunal extinctions on a large geographical scale followed by re-settlements in local areas (Carls 1985), which can be described as allopatric speciation or punctuated equilibria, according to Johnson (1975) and Eldridge \& Gould (1972). Carls (1987) argued that the rapid evolution and strong radiation of Early Devonian brachiopods found in sediments of turbid water with strong sediment transport in Western Europe is the result of rapid environmental changes and development of new ecological niches.
The brachiopods of the Eastern Iberian Chains have been briefly described by Carls (1999) with special focus on spiriferids for biostratigraphical purpose. The terebratulids of the d2c-alpha and beta beds of the Nogueras Formation have been mentioned under the name of Globithyris Cloud, 1942. Carls (1999) interpreted these forms as the phylogenetic ancestor of Rhenorensselaeria Kegel, 1913. In contrast, Schemm-Gregory (2008a) considered Lievinella Boucot, 1975 as their phylogenetic ancestors but could not study the terebratulids of the $\mathrm{d} 2 \mathrm{c}$-alpha beds for a phylogenetic interpretation of Neopaulinella (see Phylogeny section).

\section{History of research}

Species of the genus Neopaulinella Özdikmen, 2008 have been described since the $19^{\text {th }}$ century; however, their systematic assignment is a long odyssey. The first described species was the type species, $N$. guerangeri (de Verneuil, 1851), under the name Terebratula guerangeri, followed a few years later by the second species of this genus gaudryi (Oehlert 1877). Until the erection of the genus Neopaulinella these two species have been assigned to various genera: Terebratula Müller, 1776, Centronella Billings, 1859, Trigeria Bayle, 1878, Mutationella Kozłowski, 1929, Retzia King, 1850, or Xana García-Alcalde, 1972.

In his revision of Devonian Terebratulida Waagen, 1883, Cloud (1942, p. 119) pointed out that with the assignment of Bayle's Trigeria Adrieni de Verneuil, 1845 as type species of Trigeria, Trigeria became an objective synonym of Retzia, which is a rhynchospirid brachiopod. Due to the lack of material, he left the species guerangeri and gaudryi as well as several other European terebratulid species without generic assignment. In the same year Renaud (1942) described N. guerangeri from the Siegenian Taunusquarzit and the Upper Emsian Emsquarzit formations from Germany.

I have studied the brachiopod fauna of these formations and can confirm the presence of mutationellid brachiopods in the Taunusquarzit Formation. However, I have never seen these forms in the Emsquarzit Formation. A terebratulid from the Lower Emsian Vallendar Formation with similar outline and similar costae, but of much larger size, is stored in the Boucot collection in the Smithsonian Institution, Washington D.C. It is surely not $N$. guerangeri, but a taxonomic study of this form is strongly recommended to clarify its systematic position (pers. unpubl. data). The erection of Paulinella helped to solve part of the Trigeria problem (Boucot \& Racheboeuf 1987a), although the genus name was recently replaced by Neopaulinella (Özdikmen, 2008). The same authors provided a detailed description of the two Neopaulinella species, guerangeri and gaudryi. Binnekamp (1965) studied terebratulids from 
the Cantabrian Lebanza Limestone and assigned the species guerangeri to Mutationella. However, as Boucot \& Racheboeuf (1987b) pointed out, these Cantabrian guerangeri forms lack dental plates and show fewer costae than N. guerangeri, but they surely belong to Neopaulinella. García-Alcalde (1972) assigned N. guerangeri to his new genus Xana. In accordance with Boucot \& Wilson (1994), I consider this as erroneous because species of Xana show a sulcate dorsal valve and a short loop, whereas Neopaulinella shows a flat dorsal valve which never shows a sulcus. Mergl (1986) described Mutationella cf. guerangeri from Bohemia but did not give any information on the interior, so that the assignment to Neopaulinella is doubtful. Özdikmen (2008) suggested to replacing Paulinella with Neopaulinella Özdikem, 2008 due to homonymy with Paulinella Lauterborn, 1895, a genus within the Rhizipoda (see ICZN 1999, art. 23).

\section{Material and methods}

The material is preserved as articulated and isolated shells. Plaster casts were made of specimens studied by serial sections. Up to several hundred serial sections of each articulated shell were prepared using a WOKO 50P grinding machine with slice-spacing of 50 and $100 \mu \mathrm{m}$ (GZG.INV.35007: 235, GZG.INV.35008: 277, GZG.INV.35009: 313, GZG.INV.35010: 344, SMF 85615: 59, SMF 85616: 84, SMF 85617: 128, SMF 85618: 149). Acetate peels were used to record the morphological information from each slice; these were subsequently digitized using a digital camera. Three-dimensional reconstruction methods are those of Sutton et al. (2001, 2005), implemented using the custom SPIERS software suite for registration, virtual preparation, and interactive visualization. The digitized acetate peels were subsequently manually aligned with SPIERSalign and in a second step redrawn using different masks in SPIERSedit in order to reconstruct a 3D model of the internal shell morphology and the loop. The 3D images are copied out of SPIERSview and arranged in Photoshop. Furthermore, a 3D image of the internal mould of the articulated shell is shown and drawings of selected peels in order to ease comparison with data in older literature. Drawings were done with help of a camera lucida. Measurements were taken with digital calipers and rounded to $0.1 \mathrm{~mm}$. Specimens were coated with ammonium chloride prior to photography. The phylogenetic analysis was performed with the heuristic search modus of PAUP 4.10 beta (Swofford 2002). All characters are coded as ordered, regarded as Wagner characters (Wagner 1961), and are of equal weights. Consistency index (CI), retention index (RI), and rescaled consistency index (RCI) are given. A fictitious outgroup was chosen in order to assure an independent analysis. The systematics follows Lee et al. (2006) in

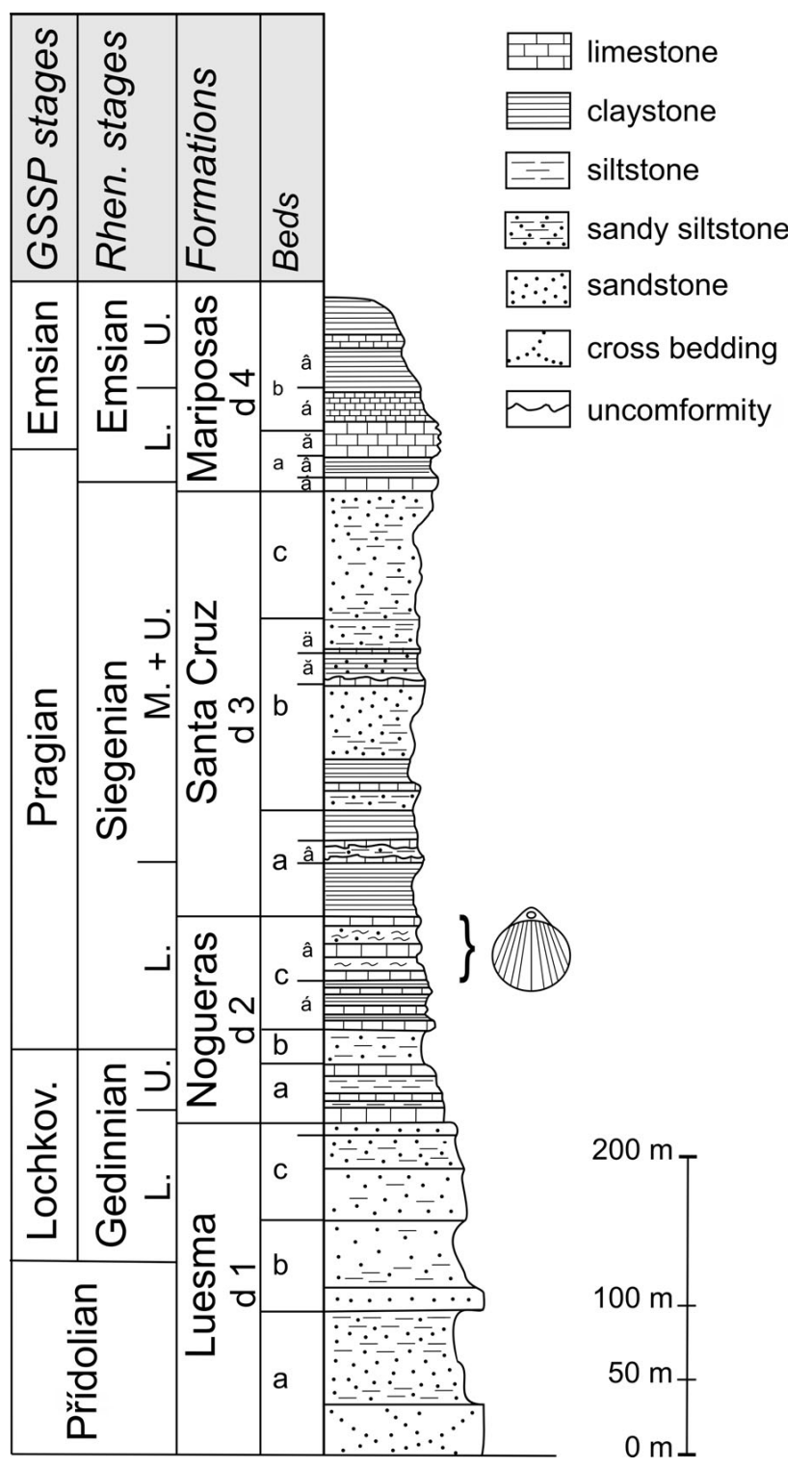

Figure 2. Lithology of the Lower Devonian in the Eastern Iberian Chains (Spain). Beds yielding Neopaulinella noguerasensis sp. nov. are marked by the brachiopod symbol. Modified after Carls (1987). Abbreviations: L. - Lower, Lochkov. - Lochkovian, M. - Middle, Rhen. Rhenish, U. - Upper.

the revised Treatise on Invertebrate Paleontology. For stratigraphic assignment, the stages "Siegenian" and "Emsian" are used in their traditional German sense because taxa of Neopaulinella occur only in the neritic facies of the Rhenohercynian. A correlation with the GSSP subdivision is given in Fig. 2.

Institutional abbreviations. - GZG.INV.: Geowissenschaftliches Zentrum der Universität Göttingen, Museum, Invertebrate Collection, Göttingen, Germany; SMF: Senckenberg Forschungsinstitut und Naturmuseum, Frankfurt am Main, Germany. 


\section{Systematic palaeontology}

Phylum Brachiopoda Duméril, 1806

Subphylum Rhynchonelliformea Williams et al., 1996

Class Rhynchonellata Williams et al., 1996

Order Terebratulida Waagen, 1883

Suborder Terebratulidina Waagen, 1883

Superfamily Stringocephaloidea King, 1850

Family Meganterididae Schuchert \& Le Vene, 1929

Subfamily Mutationellinae Cloud, 1942

Genus Neopaulinella Özdikmen, 2008

Type species. - Terebratula guerangeri de Verneuil, 1851, p. 780 .

Emended diagnosis. - Mutationellids with deeply impressed dorsal adductor field, a deeply or moderate impressed ventral muscle field, and a well-developed dorsal median septum. Ventral median septum weakly to strongly developed, rarely lacking. [Modified after Boucot \& Racheboeuf 1987a, p. 99.]

Species assigned. - Terebratula guerangeri de Verneuil, 1851; Terebratula gaudryi Oehlert, 1877; Neopaulinella noguerasensis sp. nov.

Species questionably assigned. - Centronella bergeroni Oehlert, 1885; Trigeria sarthacensis Renaud, 1942; Mutationella cf. guerangeri Mergl, 1986.

Remarks. - Differences with other genera within the Mutationellinae are discussed in Boucot \& Racheboeuf (1987a, b).

Geographic and stratigraphic occurrence. - Western and ?Central Europe, ?England, ?Turkey; Siegenian to Emsian in the traditional German sense (middle to upper Lower Devonian).

\section{Neopaulinella noguerasensis sp. nov.}

Figures 3-9, Tables 1-4

Derivation of name. - After "Nogueras", the village near the collecting locality.

Holotype. - Articulated shell stored in the Senckenberg Forschungsinstitut und Naturmuseum under the inventory number SMF 85608. Length $20.0 \mathrm{~mm}$, width $20.0 \mathrm{~mm}$, and thickness $19.3 \mathrm{~mm}$.

Type horizon and locality. - Bed d2C-beta, upper part of the Nogueras Formation (Lower Siegenian, middle Lower
Devonian), Fuente de Nogueras (Eastern Iberian Chains, Aragon, Spain). A detailed description of the collecting locality is given in Carls (1987).

Material. - 29 articulated shells (GZG.INV. 34999, 35000, 35004-35010, 35012, 35013; SMF 85607-85608, 85612-85618, 85620, 85622-85629) [8 of them used for serial sections (GZG.INV.35007-35010, SMF 85615-85618)], 6 isolated dorsal shells (GZG.INV.35001-35003; SMF $85609,85610,85630)$, and 6 ventral external shells (GZG.INV.35011, 35014, 35015; SMF 85611, 85619, $85621)$. Measurements of the material are listed in Table 1.

Diagnosis. - A neopaulinellid with a crenulate anterior margin, short and thin dental plates, clearly separated dorsal anterior and posterior adductor pairs which are strongly impressed at their posterior end, and a low and anterior faint dorsal median septum.

Description. - Form and size: Mutationellid-like small to medium-size shells that are ventribiconvex in longitudinal section, and subcircular in outline with maximum width at midlength of shell or shortly anterior of it. The ventral valve is strongly convex, and the dorsal valve almost flat. Exterior: The surface of the ventral shell is covered by 28 to 30 fine and simple costae, in rare cases up to 36. The dorsal shell shows one or two costae less. All non-medial costae are of equal size, however, the two ventral median costae and the corresponding median costa of the dorsal shell are coarser than adjacent ones (Fig. 3P-Q). Costae and furrows are of same size and rounded to angular in cross section. The anterior margin is rectimarginate, in some specimens it may be weakly sulcate. The ventral beak is gently erect, narrow, and elongate. The ventral interarea is low and small, with a large and submesothyrid foramen (Fig. 4B-C). The delthyrium is open and restricted by welldeveloped deltidial ridges (Fig. 4O). Concentric growth lamellae are developed at the anterior margin of both valves and overhang the youngest anteriormost portion of the shell. Interior of ventral valve: Hardly any development of secondary shell material is present in the ventral apical region. Fillings of the lateral apical cavities almost reach the posterior end of the filling of the umbo (Fig. 4H). Rare specimens show strong development of secondary shell material in the apical region that almost completely fills the apical cavities (Fig. 5). Dental plates are short and thin, leading to small knob-like teeth which point in an antero-dorsal direction (Figs 4O, 6K-M). The ventral muscle field is not imbedded into the shell material and ranges from barely to not impressed. Its outline is hardly recognizable in 3D reconstructions (Fig. 4H). Interior of dorsal valve: The dorsal apical region is characterized by almost no development of secondary shell material. Dental sockets are cone-shaped, pointing in a posterior 


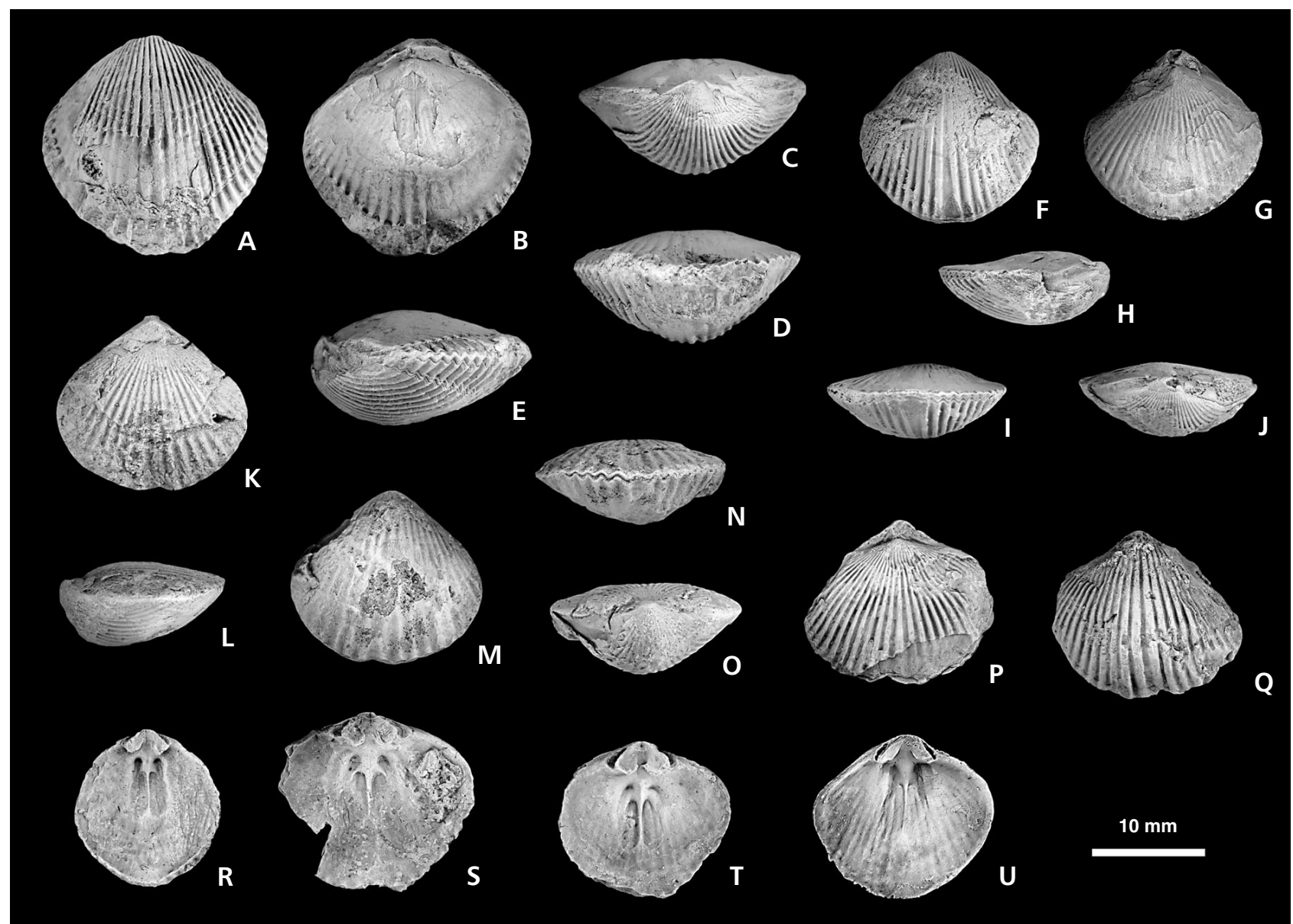

Figure 3. Neopaulinella noguerasensis sp. nov. $•$ A-E - SMF 85608, holotype. Ventral (A), dorsal (B), posterior (C), anterior (D), and lateral (E) views of articulated shell. $\bullet \mathrm{F}-\mathrm{J}-\mathrm{SMF} 85607$. Ventral (F), dorsal (G), lateral (H), anterior (I), and posterior (J) views of articulated shell. $\bullet \mathrm{K}-\mathrm{O}-\mathrm{SMF} 85613$. $\operatorname{Dorsal}(\mathrm{K})$, lateral $(\mathrm{L})$, ventral $(\mathrm{M})$, anterior $(\mathrm{N})$, and posterior $(\mathrm{O})$ views of articulated shell. $\bullet \mathrm{P}-\mathrm{Q}-\mathrm{SMF}$ 85613. Dorsal $(\mathrm{P})$ and ventral $(\mathrm{Q})$ views of articulated shell. $\bullet$ R - GZG.INV.35001. Upper view on internal dorsal shell. $\bullet \mathrm{S}-$ GZG.INV.35002. Upper view on internal dorsal shell. Note impressions of adductor scars. $\bullet$ T - GZG.INV.35003. Upper view on internal dorsal shell. Note muscle scars and cardinal plate. $\bullet U-S M F ~ 85610$. Upper view on internal dorsal shell. All figures $\times 1.5$.

direction. Inner walls of socket ridges are thick and curved over dental sockets (Fig. 5G). The cardinal plates are medially separated, triangular, thick, foraminate at posterior end, and situated almost parallel to commissural plane (Figs 3R-U, 4M, 6N). Inner hinge plates are short and connected at their anterior ends, forming a thin and transversely oriented cardinal process (Fig. 6M). Outer hinge plates are thick and laterally curved in a ventral direction. The dorsal median is septum thin, low, posteriorly coarse and anteriorly blade-like, reaching at least to the midlength of the dorsal shell, and separating the dorsal adductor field. The adductor field is, especially with respect to the posterior margin, deeply impressed into the shell material; its posterior and anterior pairs of adductor scars are clearly differentiable (Fig. 4B, R-U). The posterior adductor pair is more deeply impressed than the anterior pair, thin and elongate anteriorly, with a paddle-like outline. The anterior adductor pair is larger, elongate, and elliptical in outline.
The posterior margin of both pairs of adductor scars is distinct and rounded posteriorly. The anterior margin is less visible but bordered by a faint ridge. A deltiform and long loop extends over $2 / 3$ of valve length anteriorly (Fig. 7). Crural processes are situated at the anterior end of the posterior $1 / 3$ length of loop, sharply triangular, oriented parallel to each other, and pointing perpendicular to commissural plane in a ventral direction. Descending lamellae are parallel to one other and fused at the anterior end (Fig. 8K-L).

Discussion. - The morphological differences of Neopaulinella noguerasensis justify the erection of a new species (Table 2). The new species differs from the type species, $N$. guerangeri, in a crenulate anterior margin and lack of a sulcus. The anterior margin of $N$. guerangeri is weakly unisulcate. The dental plates in N. noguerasensis are short and thin, in $N$. guerangeri relatively long. The dorsal adductor 


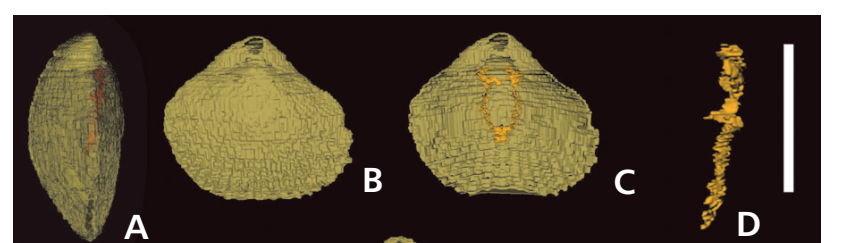

A
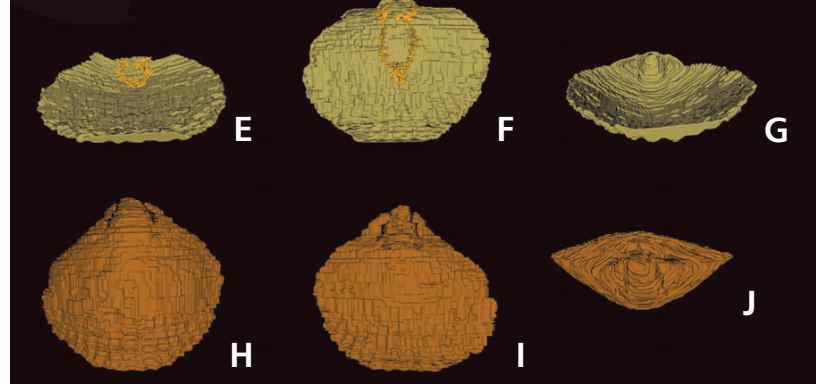

Lan $K$
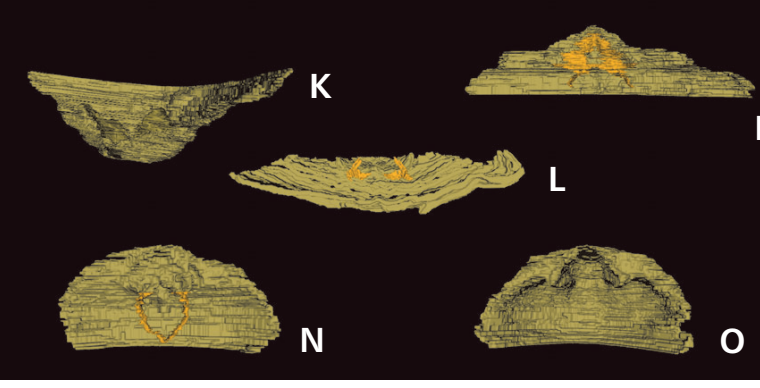

M

Figure 4. Three-dimensional reconstructions of Neopaulinella noguerasensis sp. nov. based on serial sections. • A-J - GZG.INV.35007. • A - lateral view of articulated shell with loop. Shells $50 \%$ transparent. Note orientation of loop. $\bullet \mathrm{B}-$ dorsal view of external articulated shell. $\bullet \mathrm{C}-$ upper view of ventral internal shell with loop. $\bullet \mathrm{D}$ - lateral view of loop $(\times 3.0)$, scale bar represents $5 \mathrm{~mm}$. $\bullet$ E - oblique anterior view of dorsal internal shell with loop. $\bullet \mathrm{F}$ - upper view of dorsal internal shell with loop. - $\mathrm{G}$ - oblique anterior view of ventral internal shell. $\bullet \mathrm{H}-$ ventral view of internal mould of articulated shell. $\bullet \mathrm{I}$ - dorsal view of internal mould of articulated shell. $\bullet \mathrm{J}$ - posterior view of internal mould of articulated shell. - K-M - SMF 85617. K - oblique lateral view of ventral internal shell. Note teeth and dental plates. $\mathrm{L}-$ anterior view of dorsal internal shell with loop. $\mathrm{M}$ - upper view of posterior dorsal internal shell with fragment of posterior end of loop. Note cardinal plate. $\bullet \mathrm{N}-\mathrm{O}-\mathrm{SMF} 85618$. $\mathrm{N}-$ upper view of posterior dorsal internal shell with loop. Note short length of loop with crural processes situated almost at anterior end of cardinal plate. $\mathrm{O}$ - upper view of posterior ventral internal shell. Note thickness of dental plates, deltidial ridges, and teeth. All figures $\times 1.5$, if no other indication.

field of the new species is clearly separated by a coarse median ridge into a posterior and an anterior pair of muscle scars, whereas these are hardly recognizable in the type species. Furthermore, the margin of the dorsal adductor field of $N$. noguerasensis is well defined by a fine ridge and the whole muscle field is more strongly impressed into the dorsal valve than in $N$. guerangeri, in which the anterior margin of the dorsal adductor field is unknown. The dorsal median septum of the new species is shorter than in $N$. guerangeri and posteriorly strongly thickened. Its anterior part, however, is low and fine. In $N$. guerangeri the dorsal median septum is high and of equal size throughout its whole length or rarely weakly thickened at the posterior
Table 1. Measurements of Neopaulinella noguerasensis sp. nov. Numbers in brackets show extreme values. Abbreviations: ht - holotype, INV - Inventory number, L/mm - length in $\mathrm{mm}, \mathrm{R} / \mathrm{DS}$ - number of costae on dorsal shell, R/VS - number of costae on ventral shell, $\mathrm{T} / \mathrm{mm}$ - thickness in $\mathrm{mm}, \mathrm{W} / \mathrm{mm}$ - width in $\mathrm{mm},+\mathrm{x}-$ maximum number of costae unknown.

\begin{tabular}{|c|c|c|c|c|c|}
\hline INV & $\mathrm{W} / \mathrm{mm}$ & $\mathrm{L} / \mathrm{mm}$ & $\mathrm{T} / \mathrm{mm}$ & R/DS & R/VS \\
\hline GZG.INV.34999 & 18.42 & 17.97 & 9.81 & & 26 \\
\hline GZG.INV.35000 & 21.72 & 18.84 & 10.60 & 30 & 28 \\
\hline GZG.INV.35001 & 15.17 & 13.75 & & 30 & \\
\hline GZG.INV.35002 & 12.98 & 14.00 & & $36+x$ & \\
\hline GZG.INV.35003 & 17.29 & 15.82 & & 30 & \\
\hline GZG.INV.35004 & 17.40 & 15.75 & 9.10 & 24 & 26 \\
\hline GZG.INV.35005 & 16.65 & 14.50 & 8.41 & 28 & 30 \\
\hline GZG.INV.35006 & 17.77 & 14.83 & 9.10 & 22 & 24 \\
\hline GZG.INV.35007 & 12.87 & 12.14 & 6.50 & 28 & 26 \\
\hline GZG.INV.35008 & 17.43 & 15.93 & 8.58 & 32 & 30 \\
\hline GZG.INV.35009 & 15.55 & 16.05 & 7.29 & 28 & 30 \\
\hline GZG.INV.35010 & 14.75 & 17.04 & 7.56 & 28 & 30 \\
\hline GZG.INV.35011 & 16.99 & 16.13 & 10.27 & & 28 \\
\hline GZG.INV.35012 & 19.60 & 18.57 & 10.25 & 34 & 32 \\
\hline GZG.INV.35013 & 18.53 & 17.08 & 6.07 & 28 & \\
\hline GZG.INV.35014 & 14.03 & 13.13 & & $20+x$ & \\
\hline GZG.INV.35015 & 20.83 & 11.52 & & 28 & \\
\hline SMF 85607 & 15.78 & 14.87 & 6.52 & 23 & 22 \\
\hline SMF 85608 (ht) & 20.00 & 20.04 & 19.34 & & 26 \\
\hline SMF 85609 & 12.63 & 10.81 & & & \\
\hline SMF 85610 & 10.05 & 14.43 & & 24 & \\
\hline SMF 85611 & 14.19 & 13.87 & 8.11 & & $28+x$ \\
\hline SMF 85612 & 13.67 & 16.33 & 8.32 & & $24+x$ \\
\hline SMF 85613 & 16.87 & 15.08 & 7.56 & 18 & 18 \\
\hline SMF 85614 & 19.46 & 18.46 & 9.99 & & \\
\hline SMF 85615 & 16.40 & 19.00 & 10.40 & 28 & 30 \\
\hline SMF 85616 & 15.50 & 16.10 & 8.50 & 22 & 24 \\
\hline SMF 85617 & 23.40 & 21.3 & 11.60 & 34 & 36 \\
\hline SMF 85618 & 15.00 & 14.1 & 9.00 & 26 & 28 \\
\hline SMF 85619 & & 10.88 & & 32 & \\
\hline SMF 85620 & & & & 30 & $28+x$ \\
\hline SMF 85621 & 17.97 & 20.00 & & & $20+x$ \\
\hline SMF 85622 & 16.53 & & & & \\
\hline SMF 85623 & 17.24 & 17.21 & 6.58 & 28 & 28 \\
\hline SMF 85624 & 13.82 & 14.11 & 7.22 & & 36 \\
\hline SMF 85625 & 20.99 & 20.7 & 11.30 & 20 & 20 \\
\hline SMF 85626 & 16.21 & 18.09 & 9.75 & 28 & 30 \\
\hline SMF 85627 & 18.66 & 19.52 & 13.15 & 30 & 32 \\
\hline SMF 85628 & 20.20 & 18.94 & 6.63 & 30 & 32 \\
\hline SMF 85629 & & & & & 28 \\
\hline SMF 85630 & \multicolumn{5}{|c|}{ Fragment of posterior dorsal shell } \\
\hline
\end{tabular}




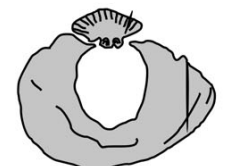

A: 0.6

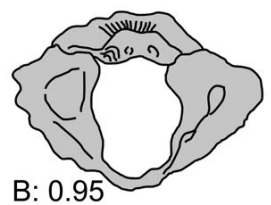

B: 0.95

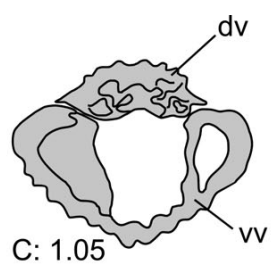

C: 1.05

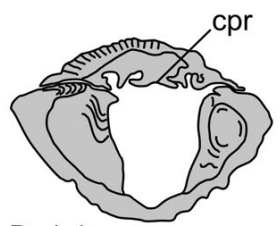

D: 1.4

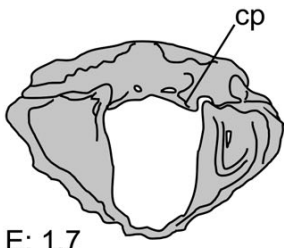

E: 1.7

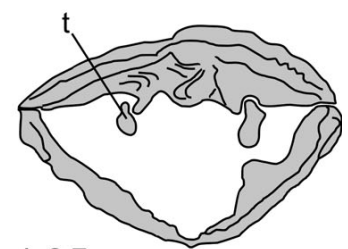

I: 2.7

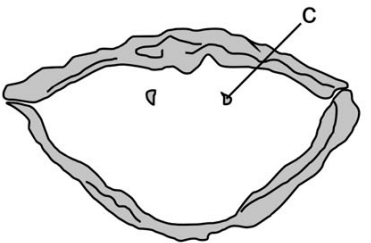

L: 3.55

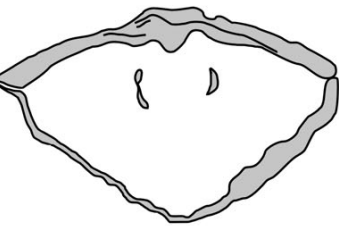

M: 3.7
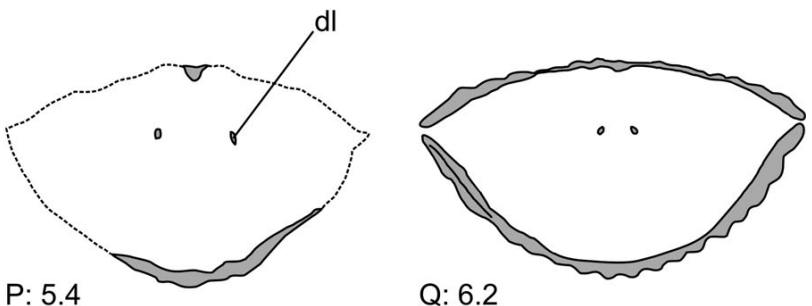

Q: 6.2

N: 4.0

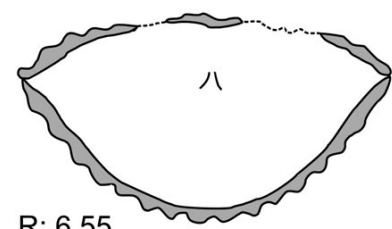

R: 6.55

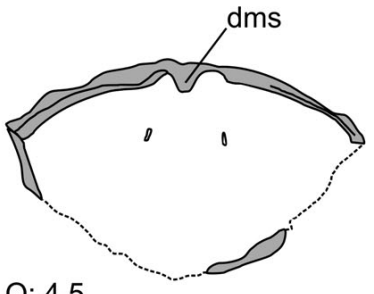

O: 4.5

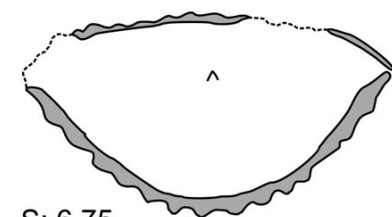

S: 6.75

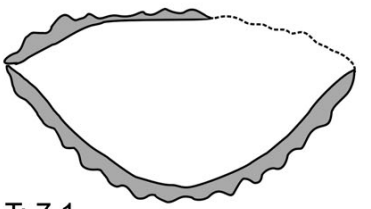

T: 7.1

Figure 5. Serial sections of Neopaulinella noguerasensis sp. nov. SMF 85618. All figures magnified $(\times 2.5)$. Sectioning perpendicular to commissural plane, sectioning distance in $\mathrm{mm}$ from posterior. Dotted line represents abraded shell. Abbreviations: $\mathrm{c}-\mathrm{crus}$, $\mathrm{cb}-\mathrm{crural}$ base, cpr - cardinal process, $\mathrm{cp}$ - cardinal plate, crpr - crural process, $\mathrm{dl}$ - decending lamella, dms - dorsal median septum, dp - dental plate, ds - dental socket, dv - dorsal valve, ss - shell structure, ssm - secondary shell material, $\mathrm{t}$ - tooth, vv - ventral valve.

margin. The angle of the ventral umbo is about $20^{\circ}$ larger and the angle of the dental plates about $12^{\circ}$ to $16^{\circ}$ larger in $N$. noguerasensis than in $N$. guerangeri. The new species differs from $N$. gaudryi in having less costae and thin dental plates. Its dorsal adductor field is short and narrow with an oval outline and the posterior and anterior pairs of adductor muscle scars being clearly divided by a coarse ridge, whereas it is large and coarse with tear-drop outline in $N$. gaudryi and the border between anterior and posterior muscle scar pairs is hardy recognizable. The dorsal median septum is lower in N. noguerasensis and posterior thickened, but high and of equal thickness in N. gaudryi. The ventral umbonal angle of $N$. noguerasensis is slightly smaller and the angle between dental plates wider than in $N$. gaudryi.

It has to be stated that for statistical analyses fewer specimens were measured than in the work by Boucot \& Racheboeuf (1987a), and as far as these data says, the ratio of length to thickness is not as low as in $N$. guerangeri and $N$. gaudryi which means that specimens of $N$. noguerasensis are slightly less curvate, however, the line of 
Table 2. Morphological comparison of species of Neopaulinella Özdikmen, 2008.

\begin{tabular}{|c|c|c|c|}
\hline & Neopaulinella noguerasensis sp. nov. & $\begin{array}{l}\text { Neopaulinella guerangeri } \\
\text { (de Verneuil, 1851) }\end{array}$ & $\begin{array}{l}\text { Neopaulinella gaudryi } \\
\text { (Oehlert, 1877) }\end{array}$ \\
\hline curvature & equi- to ventribiconvex & ventribiconvex & equibiconvex \\
\hline number of costae on ventral valve & $28-30$ & (22-44) $30-32$ & $58-76(92)$ \\
\hline anterior margin & crenulate & weakly unisulcate & crenulate \\
\hline ventral muscle field & unknown & deeply impressed & deeply impressed \\
\hline dental plates & short, thin & long, thin & short, thick \\
\hline dorsal adductor field & short, narrow with oval outline & $\begin{array}{l}\text { short, narrow, } \\
\text { anterior margin unknown }\end{array}$ & $\begin{array}{l}\text { large, } \\
\text { broad with oval to tear-drop outline }\end{array}$ \\
\hline $\begin{array}{l}\text { posterior and anterior pair of dorsal } \\
\text { adductor field }\end{array}$ & clearly separated by a coarse ridge & $\begin{array}{l}\text { border between muscle pairs hardly } \\
\text { recognizable }\end{array}$ & $\begin{array}{l}\text { border between muscle pairs hardly } \\
\text { recognizable }\end{array}$ \\
\hline dorsal median septum & $\begin{array}{l}\text { low, posteriorly thickened, anterior } \\
\text { faint }\end{array}$ & $\begin{array}{l}\text { high, posteriorly weakly thickened or } \\
\text { of equal thickness }\end{array}$ & high, equally thick \\
\hline ratio length/thickness & $2.6-1.7$ & $1.4-2.7$ & $2.4-1.6$ \\
\hline ratio length/width & $0.85-1.3$ & 1 & $0.83-0.9$ \\
\hline ventral umbonal angle & $102^{\circ}-106^{\circ}$ & $86^{\circ}$ & $111^{\circ}-125^{\circ}$ \\
\hline angle between dental plates & $57^{\circ}-61^{\circ}$ & $45^{\circ}$ & $32^{\circ}-35^{\circ}$ \\
\hline geographic occurrence & Spain (Eastern Iberian Chains) & $\begin{array}{c}\text { France, Spain, ?Belgium, ?Germany, } \\
\text { ?England, ?Turkey }\end{array}$ & France (Armorican Massif) \\
\hline stratigraphic occurrence & $\begin{array}{c}\text { Lower Siegenian } \\
\text { (middle Lower Devonian) }\end{array}$ & $\begin{array}{l}\text { Middle Siegenian to ?Emsian } \\
\text { (middle to upper Lower Devonian) }\end{array}$ & $\begin{array}{l}\text { Middle to Upper Siegenian } \\
\text { (middle Lower Devonian) }\end{array}$ \\
\hline
\end{tabular}

tendency is closer to that of $N$. gaudryi. The ratio of length to width varies a little more in $N$. noguerasensis than in the other two species, and overall the line of tendency is less steep. The ratio of length to thickness is almost the same in both species, however, the ratio of length to width varies more in the new species than in N. guerangeri (Fig. 9).

Geographical and stratigraphical occurrence. - See type locality and type horizon.

\section{Cladistical analysis of Neopaulinella}

In this work, an attempt for cladistical analysis on species level of Neopaulinella is made, even though up to now only 3 species are described for which sufficient morphological data is given. Species questionably assigned or in open nomenclature were omitted because of the lack of morphological information. Due to the few characters available and the few taxa used, the resulted cladogram shows evolutionary tendencies rather than a reliable lineage. Description and coding of characters are given in Table 3. Table 4 shows the matrix for the cladistical analysis. The cladogram demonstrates the closer relationship of guerangeri to noguerasensis (Fig. 10). The high consistency index $(\mathrm{CI}=0.9)$ indicates the lack of homoplasy and supports the definition of taxa by morphological differences discussed above and given in Table 2. The retention index is rather low for the lack of homoplasy $(\mathrm{RI}=0.67)$, subsequently, the rescaled consistency index is $\mathrm{RCI}=0.6$.

\section{Phylogeny}

Revision is recommended for the other reported finds of Neopaulinella and its questionably assigned species in order to improve the evolutionary lineage. However, I believe without doubt that the phylogenetic origin of Neopaulinella is somewhere in small mutationellid brachiopods as it was already suggested by Boucot \& Wilson (1994). An attempt at the phylogeny of taxa of Neopaulinella is given in the following: The root of Neopaulinella lies in small mutationellid brachiopods in the Eastern Iberian Chains out of which N. noguerasensis probably originated (see Boucot \& Wilson 1994, fig. 6). The new species represents the oldest species within this genus. The rather small median septa in both shells, the short and thin dental plates, the coarse ridge in the dorsal adductor field, and the posteriorly thickened dorsal median septum are interpreted as conservative morphological features. The ventral umbonal angle is widest in the new species, however, more material of all taxa of Neopaulinella should be measured to prove this argument. The increasing thickness of the dorsal median septum and the loss of the ridge separating the posterior and anterior pair of dorsal adductors are interpreted as changes to an advanced morphology within the phylogenetical lineage of the genus. During the Middle and Late Siegenian, N. guerangeri and $N$. gaudryi developed out of $N$. noguerasensis. The lineage of $N$. gaudryi became extinct during the Late Siegenian, whereas forms or descendents of $N$. guerangeri are also found in Emsian strata. Subsequently, if forms reported from the lowermost Upper Emsian Emsquarzit 


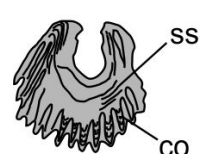

A: 0.1

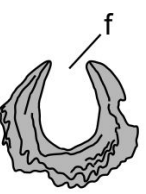

B: 0.25

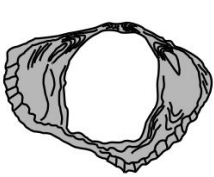

C: 0.9

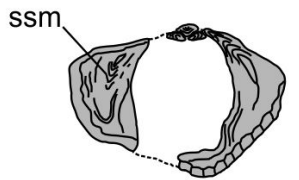

D: 2.1

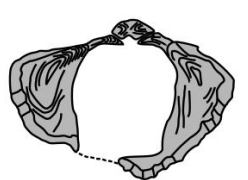

E: 1.3

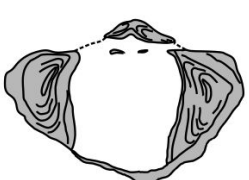

$\mathrm{F}: 1.65$

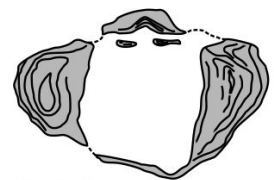

G: 1.9
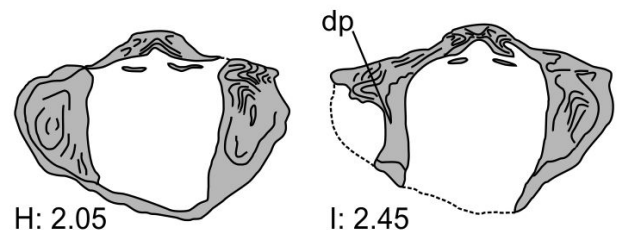

I: 2.45
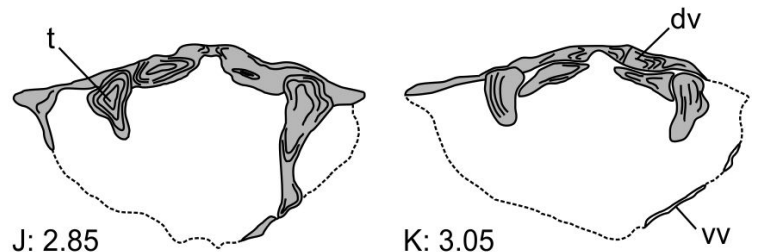

K: 3.05

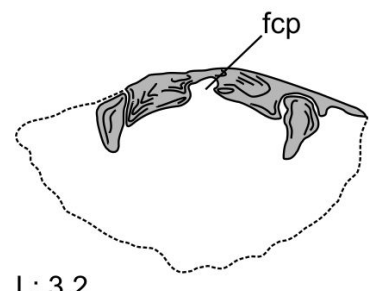

$\mathrm{L}: 3.2$
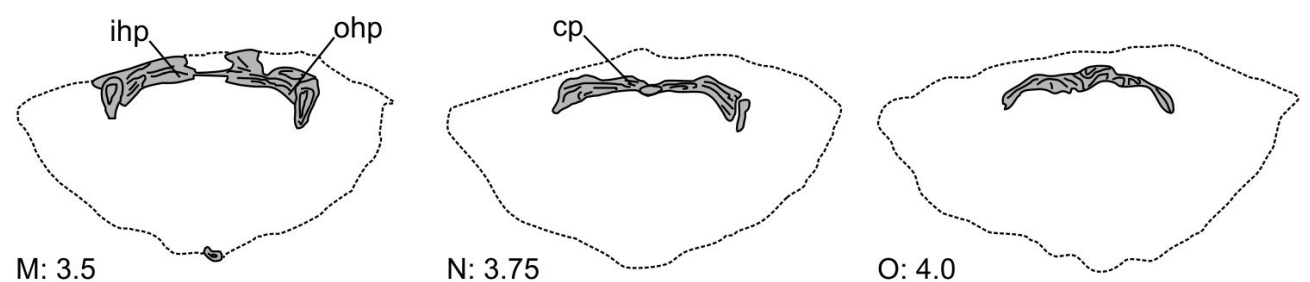

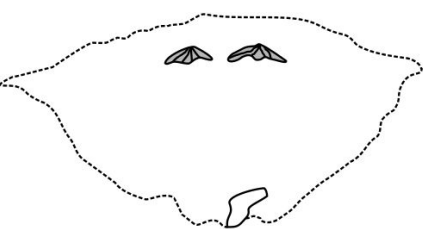

$P: 4.2$

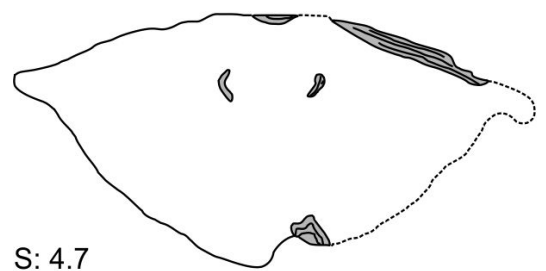

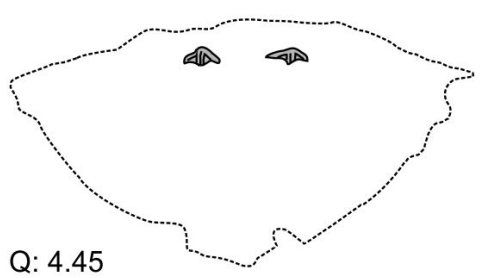

Q: 4.45
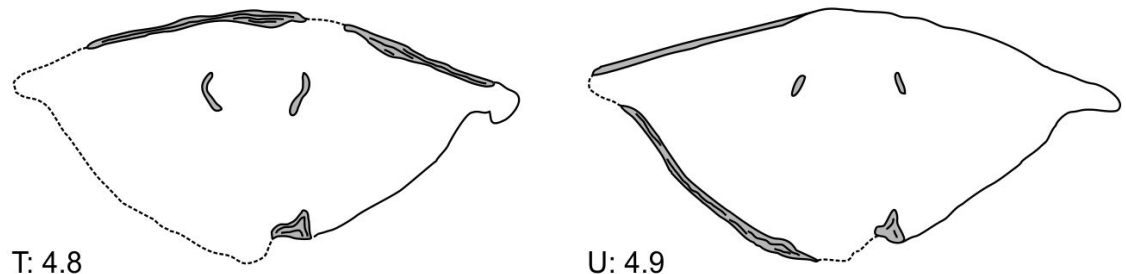

$\mathrm{U}: 4.9$

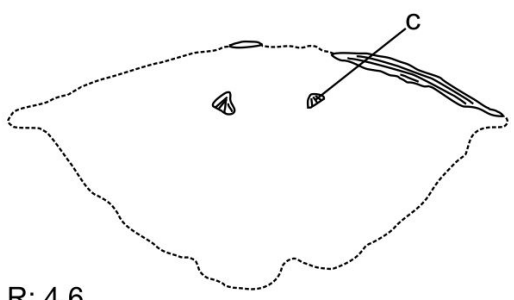

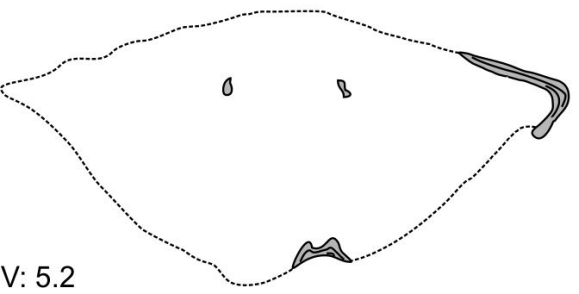

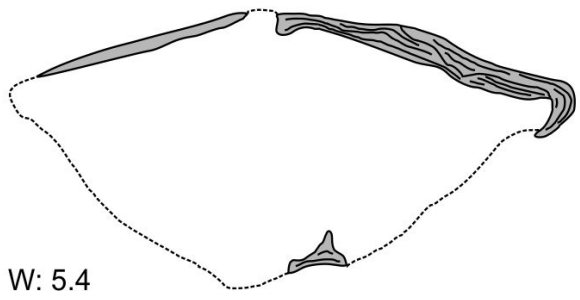

Figure 6. Serial sections of Neopaulinella noguerasensis sp. nov. SMF 85617. All figures magnified $(\times 2.5)$. Sectioning perpendicular to commissural plane, sectioning distance in $\mathrm{mm}$ from posterior. Dotted line represents abraded shell. Abbreviations: $\mathrm{c}-\mathrm{crus}$, co - brachiophore, $\mathrm{cp}-\mathrm{cardinal}$ plate, $\mathrm{dp}$ - dental plate, ds - dental socket, dv - dorsal valve, f - foramen, fcp - foramen in cardinal plate, ihp - inner hinge plate, ohp - outer hinge plate, ss - shell structure, ssm - secondary shell material, $\mathrm{t}$ - tooth, $\mathrm{vv}$ - ventral valve. 


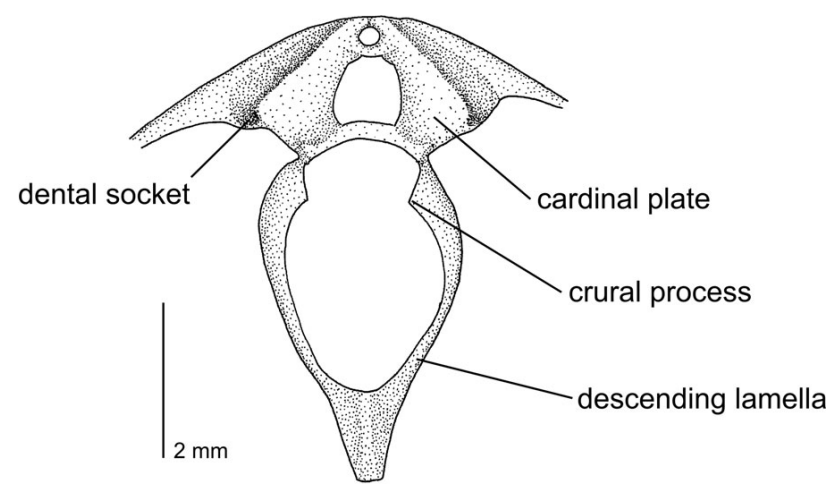

Figure 7. Neopaulinella noguerasensis sp. nov. Reconstruction of the loop and cardinalia after sectioned specimens (see Fig. 4).

Table 3. Description and coding of characters used for character matrix.

\begin{tabular}{|c|c|c|}
\hline Number & Character description & Character coding \\
\hline 1 & number of costae & below $50(0)$, above $50(1)$ \\
\hline 2 & anterior margin & crenulate (0), unisulcate (1) \\
\hline 3 & pairs of dorsal adductors & $\begin{array}{l}\text { not recognizable }(0) \text {, } \\
\text { recognizable }(1)\end{array}$ \\
\hline 4 & dorsal median septum & $\begin{array}{l}\text { posteriorly thin }(0) \text {, } \\
\text { posteriorly thick (1) }\end{array}$ \\
\hline 5 & dorsal medium septum & low (0), high (1) \\
\hline 6 & length of dental plates & short (0), long (1) \\
\hline 7 & thickness of dental plates & thin $(0)$, thick (1) \\
\hline 8 & angle of ventral umbo & below $100^{\circ}(0)$, above $100^{\circ}(1)$ \\
\hline 9 & angle between dental plates & below $50^{\circ}(0)$, above $50^{\circ}(1)$ \\
\hline
\end{tabular}

Table 4. Character matrix used for cladistics. See Table 3 for description of characters.

\begin{tabular}{llllllllll}
\hline & 1 & 2 & 3 & 4 & 5 & 6 & 7 & 8 & 9 \\
\hline$N$. guerangeri & 0 & 1 & 0 & 0 & 1 & 1 & 1 & 0 & 0 \\
$N$. gaudryi & 1 & 0 & 0 & 0 & 1 & 0 & 1 & 1 & 0 \\
$N$. noguerasensis & 0 & 0 & 1 & 1 & 0 & 0 & 0 & 1 & 1 \\
Outgroup & 0 & 0 & 0 & 0 & 0 & 0 & 0 & 0 & 0 \\
\hline
\end{tabular}

Formation are related to Neopaulinella, the genus extends up to earliest late Emsian time.

\section{Palaeoecology}

The life habit of Neopaulinella is interpreted to be somewhat similar to the life habit of Rhenorensselaeria Kegel, 1913 and Crassirensellaeria Schemm-Gregory \& Jansen, 2007 (Schemm-Gregory \& Jansen 2007). Neopaulinella probably lived in clusters (pers. comm. F. Langenstrassen 2009, GZG) attached by a pedicle on hard substrate, e.g., shell material, and oriented perpendicular to the seafloor with their anterior part oriented upwards. In contrary to the life habit of Rhenorensselaeria, I do not believe that shells of Neopaulinella were partly buried in the sediment because the shell material studied lacks a line marking the upper sediment boundary. Furthermore, in a carbonate environment more hard substrate is available, represented by isolated shells or reef hardground, than in the clayey seafloor and turbid water with hardly any hard substrate in which the rhenorensselaerid genera lived.

The zigzag commissure of brachiopods results in a longer commissure in comparison to an unfolded shell. Nutrient water is rather poor in carbonate environments (Rupke 1965) and a longer commissure provides a greater surface of exchanges and more nutrient water could be filtered (Schemm-Gregory 2010). The brachiopod could have benefited from this physiological advantage, too. In a second step the zigzag commissure reduced the distance between the valve margins so that coarse particles could not enter into the mantle cavity (Rudwick 1964). If taxa identified as $N$. guerangeri from the Taunusquarzit or Emsquarzit formations turn out to be forms of Neopaulinella, it would support the theory of the zigzag commissure mentioned above. Neopaulinella guerangeri shows a quite coarse ornamentation within the genus and these two formations represents environments of turbid "dirty" water with much suspension (Stets \& Schäfer 2002).

\section{Palaeobiogeography}

The Early Devonian is characterized by an increasing endemism that gets lost step-by-step with the beginning of the Late Emsian. The different Early Devonian faunal provinces have been described by Boucot (1975), Boucot \& Blodgett (2001), and Schemm-Gregory (2007, 2009). Boucot \& Wilson (1994) pointed out that the Early Devonian provincialism is reflected by the European terebratulid forms Xana and Paulinella (now Neopaulinella). I agree with these authors and consider these forms as Gondwanan forms because Spain and France belong to former Gondwana (today's North Africa and Western Europe) which are distinct from today's Central Europe (Jansen 2001, Schemm-Gregory 2008a). However, forms described as Neopaulinella guerangeri from Central Europe and Turkey have to be revised in order to prove the Gondwanan endemism of Xana and Neopaulinella. It has to be stressed that the Istanbul Basin from where guerangeri forms are reported belongs to the northern Gondwanan terrane, too, as already discussed by Schemm-Gregory (2008b). On the other hand a migration pathway between Central and Western Europe existed during the Middle Siegenian and the Siegenian/Emsian boundary interval reflected by the terebratulid genus Rhenorensselaeria (Schemm-Gregory 2008a). Faunal affinities between the Armorican Massif and the Eastern Iberian Chains were shown by Carls (1987) 

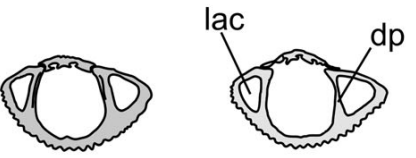

A: 1.25

B: 1.8

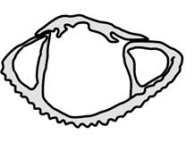

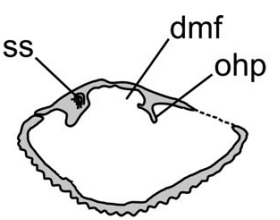

D: 2.6

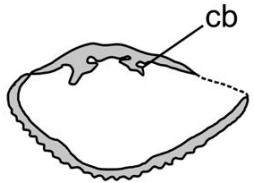

E: 2.75

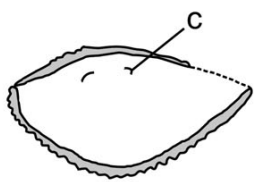

$F: 3.1$

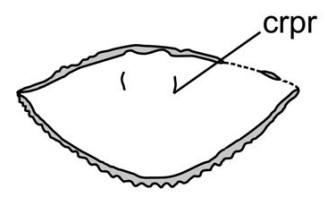

G: 3.75

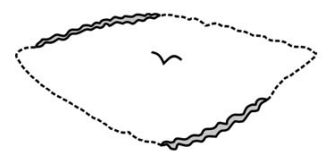

K: 6.5

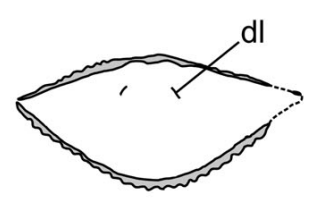

$\mathrm{H}: 4.3$

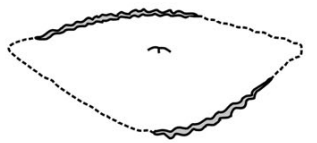

L: 6.6

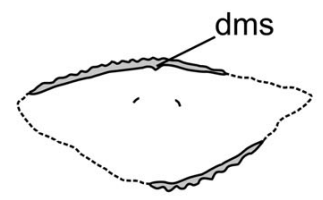

I: 5.9

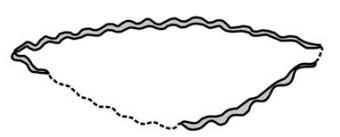

M: 9.55

Figure 8. Serial sections of Neopaulinella noguerasensis sp. nov. GZG.INV.35007. All figures magnified ( $\times 2.5)$. Sectioning perpendicular to commissural plane, sectioning distance in mm from posterior. Dotted line represents abraded shell. Abbreviations: $\mathrm{c}-\mathrm{crus}$, $\mathrm{cb}-\mathrm{crural}$ base, $\mathrm{crpr}-\mathrm{crural}$ process, $\mathrm{dl}$ - descending lamella, dp - dental plate, dmf - dorsal muscle field, dms - dorsal median septum, dv - dorsal valve, lac - lateral apical cavity, ohp - outer hinge plate, vv - ventral valve.

and Gourvennec (1989) who discussed the occurrence of Torosospirifer Gourvennec 1989, resp., spiriferids of the roussaui group, Athyris undata (Defrance, 1828), and Vandercammenina trigeri (de Verneuil, 1850). Jahnke (1971) correlated the Erbslochgrauwacke of the Kellerwald (Rheinisches Schiefergebirge, Germany) with the Eastern Iberian Chains due to the presence of Vandercammenina trigeri and Mauispirifer sp. H, however, he considered the Erbslochgrauwacke as part of today's Central Europe. The occurrence of Filispirifer fallax (Giebel, 1858) proves that the Erbslochgrauwacke is part of the northern Gondwana terranes and presents a block that probably slipped northward (Jansen 2001, Schemm-Gregory 2008c). The Lower Devonian of Western Europe can also be correlated with the Meguma Zone (Nova Scotia) with the presence of Vandercammenina Boucot, 1975 and Ovetensispirifer Schemm-Gregory, 2008b in both regions, however, Neopaulinella has not yet been reported from Nova Scotia (Bouyx et al. 1992; Boucot 1960, 1975; Schemm-Gregory 2008b).

Neopaulinella appears in Siegenian and Emsian strata. The new species occurs only in the Eastern Iberian Chains where it is restricted to the Early Siegenian. During Middle and Late Siegenian time the genus migrated to the Cantabrian Mountains and the Armorican Massif. It is represented by the species guerangeri in both regions but only by gaudryi in the Cantabrian Mountains. In the latest Siegenian and Early Emsian it is questionably reported from Central Europe, southern England, and Turkey; as mentioned above, this material has to be revised to prove the identification and confirm the systematic position. I have briefly studied material from the Siegenian and Emsian of Devon and Cornwall (southern England) and the Istanbul Basin (Turkey). Externally similar but much smaller specimens resemble Mutationella Kozłowski, 1929 rather than Neopaulinella, however, I have not seen the material identified as Neopaulinella guerangeri yet. Carls \& Valenzuela-Ríos (1998) already showed close affinities between the Eastern Iberian Chains and the Rheinisches Schiefergebirge and argued for a Middle Siegenian transgression resulting in a faunal exchange between these regions. Schemm-Gregory (2008a) discussed migration paths of centronellid brachiopods which are widely related to Neopaulinella. The Middle Siegenian transgression would be the only possibility for a pathway between a northern Gondwana terrane and the Rheinisches Schiefergebirge through which forms related to $N$. guerangeri found in the Taunusquarzit Formation would have been able to migrate to Central Europe.

\section{Conclusions}

Neopaulinella noguerasensis represents the earliest species of Neopaulinella and proves the origin of the genus from mutationellid brachiopods in the Eastern Iberian Chains. With the Middle Siegenian transgression questionable forms of Neopaulinella have migrated to Central Europe, southern England, and Turkey and support the theory of a pathway between Western and Central Europe during 


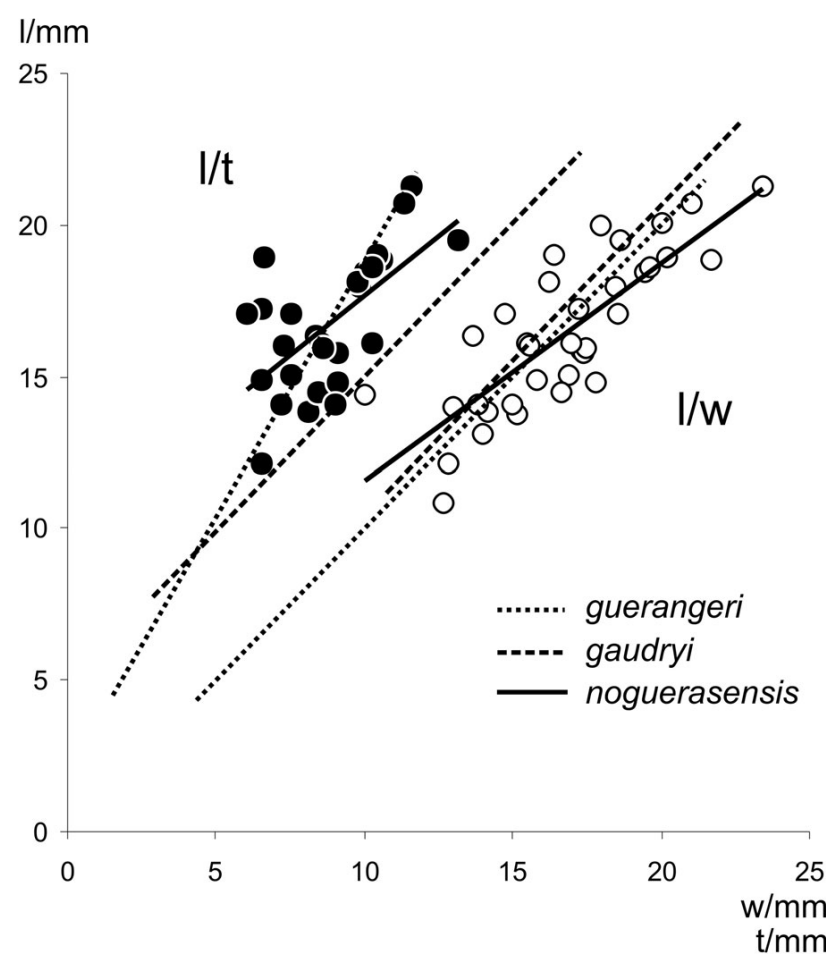

Figure 9. Diagram of the $1 / \mathrm{t}$ and $1 / \mathrm{w}$ ratios of species of Neopaulinella Özdikmen, 2008 based on measurement in Table 1. Abbreviations: 1 - length, $\mathrm{t}$ - thickness, $\mathrm{w}$ - width.

this time period. The morphological comparison and cladistical analysis demonstrate the independent coeval evolution of taxa of Neopaulinella which is another proof of Early Devonian endemism even on a regional scale within Western and Central Europe. The method of 3D reconstructions allows a detailed study of the shell interior including the development of the loop and justifies the erection of the new species. A revision of taxa questionably assigned to Neopaulinella using this method would be desirable to improve the knowledge of this genus.

\section{Acknowledgements}

The author thanks Ulrich Jansen (SMF) and Mike Reich (GZG) for giving her access to their brachiopod collections. Erika Dörner (Goethe Universität, Frankfurt am Main) and Juliane Eberhardt (SMF) kindly prepared the serial sections. I am grateful to Maria Helena Henriques (Centro de Geociências da Universidade de Coimbra) for providing me with working space to finish this manuscript. Jau-Chyn (Teresa) Liao (Universidad de Valencia) kindly supplied me with literature. Peter Carls (Technische Universitat Braunschweig), Frank Langenstrassen (GZG), and José Ignacio (Nacho) Valenzuela-Ríos (Universidad de Valencia) gave helpful comments on the lithology, geology, and palaeontology of the Eastern Iberian Chains. The work much benefited from the reviews by Robert B. Blodgett (Anchorage, USA) and Arthur J. Boucot (Oregon State University, Corvallis, USA).

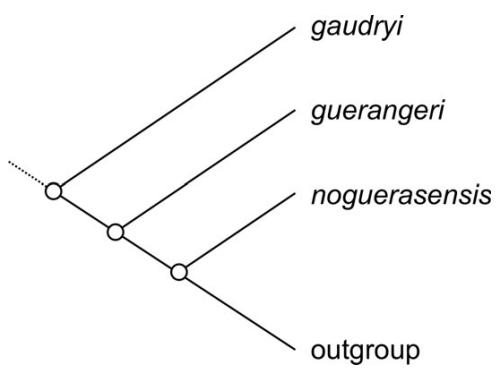

Figure 10. Cladogram showing the most plausible parsimonious tree resulting from an analysis of the character matrix in Table 4 with PAUP 4.10 beta (length $=10, \mathrm{CI}=0.9, \mathrm{RI}=0.67, \mathrm{RCI}=0.6$ ).

\section{References}

BAYLE, E. 1878. Fossiles principaux des terrains. Explication de la carte géologique de la France 4, 1-157.

Billings, E. 1859. On some new genera and species of Brachiopoda from the Silurian and Devonian rocks of Canada. Canadian Nature and Geology 4, 1-131.

BinneKAmP, J.G. 1965. Lower Devonian brachiopods and stratigraphy of North Palencia (Cantabrian Mountains, Spain). Leidse Geologische Mededelingen 33, 1-62.

Boucot, A.J. 1960. Implications of Rhenish Lower Devonian brachiopods from Nova Scotia. International Geological Congress, XXI session, Part XII, 129-137.

Boucot, A.J. 1975. Evolution and extinction rate controls. 427 pp. Elsevier, Amsterdam.

Boucot, A.J. \& Blodgett, R.B. 2001. Silurian-Devonian biogeography, 335-344. In BRunton, C.H.C., Cocks, L.R.M. \& Long, S.L. (eds) Brachiopods Past and Present. The Systematics Association Special Volume Series 63.

Boucot, A.J. \& Racheboeuf, P. 1987a. Paulinella nov. gen., new Devonian terebratulid (Brachiopoda) from Europe. Geobios 20,97-121. DOI 10.1016/S0016-6995(87)80059-1

Boucot, A.J. \& Racheboeuf, P. 1987b. New European Paulinella occurrences. Geobios 20, 701. DOI 10.1016/S0016-6995(87)80025-6

Boucot, A.J. \& WiLson, R.A. 1994. Origin and early radiation of terebratuloid Brachiopods: Thoughts provoked by Prorensselaeria and Nanothyris. Journal of Paleontology 68(5), 1002-1025.

Bouyx, E., Blaise, J., Brice, D., Gourvennec, R., Lardeux, H. \& Le Menn, J. 1992. Implications paléogéographiques des affinités nordgondwaniennes et rhénanes des faunes dévoniennes de la zone de Meguma (Appalaches septentrionnales). Comptes Rendus de l'Académie des sciences Paris 315 (série 2), 337-343.

CARLs, P. 1969. Zur Einstufung des Devon der östlichen Guadarrama (Spanien). Senckenbergiana lethaea 50(1), 67-79.

CARLS, P. 1971. Stratigraphische Übereinstimmungen im höchsten Silur und tiefen Unter-Devon zwischen Keltiberien (Spanien) und Bretagne (Frankreich) und das Alter des Grès de Gdoumont (Belgien). Neues Jahrbuch für Geologie und Paläontologie, Mitteilungen 1971(4), 195-212.

CARLs, P. 1974. Die Proschizophoriinae (Brachiopoda: Silurium-Devon) der Östlichen Iberischen Ketten (Spanien). Senckenbergiana lethaea 55(1/5), 153-227. 
CARLS, P. 1975. Zusätzliche Conodonten-Funde aus dem tieferen Unter-Devon Keltiberiens (Spanien). Senckenbergiana lethaea 56(4/5), 399-428.

CARLS, P. 1977. The Silurian-Devonian boundary in northeastern and central Spain, 143-158. In Martinsson, A. (ed.) The Silurian-Devonian boundary. Final report of the Committee on the Silurian-Devonian Boundary within IUGS Commission on Stratigraphy and a state of the art report for Project Ecostratigraphy. IUGS Series A, 5.

CARLs, P. 1985. Howellella (Hysterohowellella) knetschi (Brachiopoda, Spiriferacea) aus dem tiefen Unter-Gedinnium Keltiberiens. Senckenbergiana lethaea 65(4/6), 297-326.

CARLs, P. 1986. Neue Arten von Vandercammenina und Hysterolites (Brachiopoda, Acrospiriferinae; Devon). Senckenbergiana lethaea 67(1/4), 33-41.

CARLs, P. 1987. Ein Vorschlag zur biostratigraphischen Redefinition der Grenze Gedinnium/Siegenium und benachbarter Unter-Stufen. 1. Teil: Stratigraphische Argumente und Korrelation. Courier Forschungsinstitut Senckenberg 92, 77-121.

CARLS, P. 1988. The Devonian of Celtiberia (Spain) and Devonian Paleogeography of SW Europe, 421-466. In McMilLan, N.J., Embry, A.F. \& Glass, D.J. (eds) Devonian of the World. Vol. 1. Regional Syntheses; Canadian Society of Petroleum Geologists, Calgary, Alberta.

CARls, P. 1996a. Keltiberien, 278, column R142di96. In Weddige, K. (ed.) Devon-Korrelationstabelle. Senckenbergiana lethaea $76(1 / 2)$.

CARls, P. 1996b. Brachiopoden, Brachiopoden-'Schritte' Keltiberien, 277, column B121di96. In WedDIGE, K. (ed.) Devon-Korrelationstabelle. Senckenbergiana lethaea 76(1/2).

CARLs, P. 1999. El Devónico de Celtiberia y sus fósiles, 101-164. In Gámez Vintaned, J.A. \& Liñán, E. (eds) VI Jornadas Aragonesas de Paleontología. 25 años de Paleontología Aragonesa. Homenaje al profesor Leandro Sequeiros.

CARLS, P. \& GANDL, J. 1967. The Lower Devonian of the Eastern Iberian Chains (NE Spain) and the distribution of the Spiriferacea, Acastavinae and Asteropyginae, 453-464. In Oswald, D.H. (ed.) International Symposium on the Devonian System, Calgary 1967. Vol. 2. Alberta Society of Petroleum Geologists, Calgary, Alberta.

Carls, P. \& Gandl, J. 1969. Stratigraphie und Conodonten des Unter-Devons der Östlichen Iberischen Ketten (NE-Spanien). Neues Jahrbuch für Geologie und Paläontologie - Abhandlungen 132(2), 155-218.

Carls, P., Gandl, J., Groos-Uffenorde, H., JahnKe, H. \& WalLISER, O.H. 1972. Neue Daten zur Grenze Unter-/MittelDevon. Newsletter of Stratigraphy 2(3), 115-147.

Carls, P., Jahnke, H., Lusznat, M. \& Racheboeuf, P.R. 1982. On the Siegenian stage, 181-198. In ZiegLeR, W. \& WeRnER, R. (eds) On Devonian Stratigraphy and Palaeontology of the Ardenno-Rhenish mountains and related Devonian matters. Courier Forschungsinstitut Senckenberg 55.

Carls, P., Meyn, H. \& Vespermann, J. 1993. Lebensraum, Entstehung und Nachfahren von Howellella (Iberohowellella) hollmanni n. sg., n. sp. (Spiriferacea; Lochkovium, UnterDevon). Senckenbergiana lethaea 73(2), 227-267.

Carls, P. \& Valenzuela-Ríos, J.I. 1998. The ancestry of the Rhenish Middle Siegenian brachiopod fauna in the Iberian Chains and its palaeozoogeography (Early Devonian). Revista
Española de Paleontología, special issue, Homenaje al Prof. Gonzalo Vidal, 123-142.

Cloud, P.E. JR. 1942. Terebratulid brachiopods of the Silurian and Devonian. Geological Society of America, Special Paper $38,1-182$.

Defrance, M.J.L. 1828. Térébratules fossiles, 147-167. In Cuvier, G. (ed.) Dictionnaire des Sciences Naturelles 52. F.G. Levrault \& Le Normant, Paris \& Strasbourg.

DuMÉRIL, A.M.C. 1806. Zoologie analytique ou méthode naturelle de classification des animaux. 344 pp. Allais, Paris.

ElDRIDGE, N. \& Gould, S.J. 1972. Punctuated equilibria: an alternative to phyletic gradualism, 82-115. In Schopf, T.J. (ed.) Models in Paleobiology. W.H. Freeman, San Francisco.

GANDL, J. 1972. Die Acastavinae und Asteropyginae (Trilobita) Keltiberiens (NE-Spanien). Abhandlungen der senckenbergischen naturforschenden Gesellschaft 530, 1-184.

García-Alcalde, J.L. 1972. Braquiópodos Devónicos de la Cordillera Cantábrica. 2) Género Xana García-Alcalde, n. gen. Terebratulida, Stringocephalacea. Breviora Geologico Asturica, Ano XVI 1, 4-12.

Giebel, C.G. 1858. Die Silurische Fauna des Unterharzes nach Herrn C. Bischoff's Sammlung. Abhandlungen des Naturwissenschaftlichen Vereines der Provinzen Sachsen und Thüringen 1, 25-70.

Gourvennec, R. 1989. Brachiopodes Spiriferida du Dévonien inférieur du Massif Armoricain. Systématique, paléobiologie, évolution, biostratigraphie. Biostratigraphie du Paléozoïque 9, 1-281.

ICZN 1999. International Code of Zoological Nomenclature. xxix $+306 \mathrm{pp} .4^{\text {th }}$ ed. International Trust for Zoological Nomenclature, c/o The Natural History Museum, London.

JAHNKE, H. 1971. Fauna und Alter der Erbslochgrauwacke (Brachiopoden und Trilobiten, Unter-Devon, Rheinisches Schiefergebirge und Harz). Göttinger Arbeiten zur Geologie und Paläontologie 9, 1-105.

Jansen, U. 2001. Morphologie, Taxonomie und Phylogenie unter-devonischer Brachiopoden aus der Dra-Ebene (Marokko, Prä-Sahara) und dem Rheinischen Schiefergebirge (Deutschland). Abhandlungen der Senckenbergischen Naturforschenden Gesellschaft 554, 1-389.

Jansen, U., Lazreq, N., Plodowski, G., Schemm-Gregory, M., Schindler, E. \& Weddige, K. 2007. Neritic-pelagic correlation in the Lower and basal Middle Devonian of the Dra Valley (S Anti-Atlas, Moroccan Pre-Sahara). Geological Society, Special Publications 278, 9-37. DOI 10.1144/SP278.2

Johnson, J.G. 1975. Allopatric speciation in fossil brachiopods. Journal of Paleontology 49(4), 646-661.

Kegel, W. 1913. Der Taunusquarzit von Katzenelnbogen. Abhandlungen der preussischen geologischen Landesanstalt, Neue Folge 76, 1-162.

KInG, W. 1850. The Permian fossils of England. 253 pp. Palaeontographical Society, London.

KozŁowski, R. 1929. Les Brachiopodes Gothlandiens de la Podolie Polonaise. Palaeontologica Polonica 1, 1-254.

Lauterborn, R. 1895. Protozoenstudien II. Paulinella chromatophora nov. gen., nov. spec., ein beschalter Rhizopode des Süßwassers mit blaugrünen chromatophorenartigen Einschlüssen. Zeitschrift für wissenschaftliche Zoologie 59, $537-544$. 
Lee, D.E., Dagys, A.S., Smirnova, T.N., Sun Dongli \& Jin Yuan 2006. Terebratulidina, 1994-2018. In KAESLER, R.L. (ed.) Treatise on Invertebrate Paleontology, part $\mathrm{H}$, Brachiopoda, revised, vol. 5. The Geological Society of America, Inc. \& University of Kansas, Boulder, Colorado, \& Lawrence, Kansas.

Mergl, M. 1986. Rare Devonian terebratulids (Brachiopoda) from the Prague Basin (Bohemia). Věstník Ústředního ústavu geologického 61, 229-232.

Müller, O.F. 1776. Zoologiae Danicae Prodomus seu Animalium Daniae et Norvegiae indignenarum characters, nomina et synonyma imprimis popularia. xxxii +282 pp. Printed by the author, Harniae.

OehLERT, D. 1877. Sur les fossils dévoniens du Département de la Mayenne. Bulletin de la Société géologique de France, Paris $5,3^{\text {rd }}$ series, 578-603.

Oehlert, D. 1885. Description de deux Centronelles du Dévonien inférieur de l'Ouest de la France. Bulletin de la Société d'Études scientifiques d'Angers, Angers, 1882-1883, 24-28.

ÖZDiKMEN, H. 2008. Nomenclatural changes for eight genus group names in Brachiopoda. Munis Entomology \& Zoology $3(1), 345-354$.

Renaud, A. 1942. Le Dévonien du Synclinorium médian BrestLaval. Mémoires de Societé Géologique et Minéralogie de Bretagne 7, 1-439.

Rudwick, M.J.S. 1964. The function of zigzag deflections in the commissures of fossil brachiopods. Palaeontology 7(4), $135-171$.

RupKe, J. 1965. The Esla Nappe, Cantabrian Mountains. Leidse geologische Mededelingen 32, 1-74.

Schemm-Gregory, M. 2007. New Aspects of Early and Middle Devonian Brachiopod Palaeobiogeography. $1^{\text {st }}$ Symposium International de Palaéobiogéographie. Abstracts 89. Paris.

SCHEMM-GRegory, M. 2008a. A new terebratulid brachiopod species from the Siegenian (middle Lower Devonian) of the Dra Valley, Morocco. Palaeontology 51(4), 793-806.

DOI 10.1111/j.1475-4983.2008.00772.x

SCHEMm-Gregory, M. 2008b. New interpretations of the phylogeny and taxonomy of delthyridoid spiriferids (Brachiopoda, Lower and Middle Devonian). Bulletin of Geosciences 83(4), 401-448. DOI 10.3140/bull.geosci.2008.04.401

SCHEMm-GREGORY, M. 2008c. A new species of Filispirifer (Brachiopoda: Delthyridoidea) from the Dra Valley, Morocco (Lower Devonian). Zootaxa 1739, 53-68.

SCHEMm-Gregory, M. 2009. Phylogeny, taxonomy, and palaeobiogeography of delthyridoid spiriferids (Brachiopoda, Silurian to Devonian). 610 pp. Ph.D. thesis, Wolfgang Goethe-Universität Frankfurt, Frankfurt am Main, Germany.

SCHEMm-Gregory, M. 2010. Leonispirifer leonensis gen. et sp. nov., a rare new delthyridoid spirifer from northern Spain (Brachiopoda, Lower Devonian). Paläontologische Zeitschrift 84(3), 345-364. DOI 10.1007/s12542-009-0048-y

Schemm-Gregory, M. \& JAnsen, U. 2007. A new genus of terebratulid brachiopod from the Siegenian of the Rhenisches Schiefergebirge. Acta Palaeontologica Polonica 52(2), 413-422.

Schemm-Gregory, M. \& Jansen, U. 2009. The Silurian of the Goldsteintal (Rheinisches Schiefergebirge, Germany), 339-340. In Corriga, M. \& Piras, S. (eds) Time and life in the Silurian: a multidisciplinary approach. Abstracts. Rendiconti de la Società Paleontologica Italiana 3(3).

Schuchert, C. \& Le Vene, C.M. 1929. Brachiopoda (Generum et Genotyporum Index et Bibliographia), 1-140. In POMPECKJ, J.F. (ed.) Fossilium Catalogus I: Animalia, pars 42: Brachiopoda. W. Junk, Berlin.

Stets, J. \& SCHÄFER, A. 2002. Depositional Environments in the Lower Devonian Siliciclastics of the Rhenohercynian Basin (Rheinisches Schiefergebirge, W-Germany) - Case Studies and a Model. Contributions to Sedimentary Geology 22, 1-78.

Sutton, M.D, Briggs, D.E.G., Siveter, David J. \& Siveter, DeREK J. 2001. Methodologies for the visualization and reconstruction of three-dimensional fossils from the Silurian Herefordshire Lagerstätte. Paleontologia Electronica 4(1), art. 2, http://palaeo-electronica.org/2001_1/s2/issue1_01.htm, 1-17.

Sutton, M.D, Briggs, D.E.G., Siveter, David J. \& Siveter, DEREK J. 2005. Silurian brachiopods with soft-tissue preservation. Nature 436, 1013-1015. DOI 10.1038/nature03846

Swofford, D.L. 2002. PAUP*: Phylogenetic Analysis Using Parsimony (*and other Methods), v. 4b10. Sinauer, Sunderland/MA.

Verneuil, E. DE 1845. Paléontologie, Mollusques, Brachiopods, 17-395. In Murchison, R.I., Verneuil, E. DE \& KeyserLing, A. de (eds) Géologie de la Russie d'Europe et des Montagnes de l'Oura 2(3), Paléontologie.

Verneuil, E. DE 1850. Note sur les fossiles dévoniens du distrikt de Sabero (Léon). Bulletin de la Société géologique de France $7(1), 155-186$.

Verneuil, E. DE 1851. Tableau des fossils du terrain dévonien du department de la Sarthe. Bulletin de la Société géologique de France, Paris 7(2), 778-785.

WAagen, W.H. 1883. Salt Range fossils, Part 4 (2) Brachiopoda. Palaeontologica Indica, Memoires 13, 391-546.

Wagner, W.H. 1961. Problems in the classification of ferns. Recent Advances in Botany 1, 841-844.

Williams, A., Carlson, S.J., Brunton, C.H.C., Holmer, L.E. \& Popov, L.E. 1996. A supra-ordinal classification of the Brachiopoda. Philosophical Transaction of the Royal Society of London (series B) 351, 1171-1193.

DOI 10.1098/rstb.1996.0101 